ETIS analysis as it is potentially a key country for the export and transit of large consignments of illicit ivory (Milliken et al., 2013, Monitoring of Illegal Trade in Ivory and other Elephant Specimens, CoP16 Doc 53.2.2). Angola is home to two species of elephant, the forest elephant Loxodonta cyclotis in the north and the savannah elephant Loxodonta africana in the north-east and south. Under Angolan legislation it is illegal to kill elephants without a hunting licence and possession and trade of ivory requires special permission. Despite these laws, to the best of our knowledge no enforcement or regular monitoring of the ivory trade is conducted by Angolan authorities.

In 2005 the wildlife trade monitoring organization TRAFFIC surveyed this trade in Angola, mostly in and near the capital Luanda, and found significant and open trade in ivory (Milliken et al., 2006, No Peace for Elephants, TRAFFIC, Cambridge). One market, the Benfica craft market south of Luanda, was responsible for over $90 \%$ of the ivory for sale. This included 24 polished tusks and 183 large carvings. On 29 August and 19 September 2013 we had the opportunity to revisit the Benfica craft market, where we found ongoing open sale of tusks and ivory carvings. During the second visit we systematically counted and photographed all larger pieces of ivory and were able to count c. $60-70 \%$ of the smaller items for sale (these were often displayed in large piles, hampering counting of individual items). The market is divided into two sections. The first section is arranged with tables in several aisles, where wooden sculptures, animal products, paintings and small items are displayed; the second section comprises mainly large wooden sculptures and fabrics. All the ivory was displayed in the first section and it was by far the most common animal product on sale. A total of 27 stalls were observed displaying ivory, 10 exclusively. The items for sale included 50 polished ivory tusks as well as 92 large $(>20$ $\mathrm{cm})$ and 70 medium-sized $(10-20 \mathrm{~cm})$ carvings. Smaller items included 125 necklaces, 342 bangles (two-thirds large and thick, one-third thin), 400 chopsticks (displayed in bundles of 20), 93 name seals and 892 other small items (including hair pieces, rings, combs, earrings and 'lion teeth').

Although all quotes were given in the national currency it was clear the traders were targeting foreign tourists. The presence of name seals, chopsticks and Buddha and dragon figurines, as well as the presence of Chinese-speaking clientele, suggest a direct link to East Asian markets. The shape and size of the tusks on display indicated that the ivory originated from African forest elephants as opposed to savannah elephants but the exact origin is unknown. Traders indicated that the ivory originated from within Angola but in 2005 the TRAFFIC team reasoned convincingly that the ivory was more likely to originate from the Democratic Republic of Congo and the Republic of Congo than from Angola. Our observations confirm that there is still an open and significant trade in ivory at Benfica but with more whole tusks for sale than in 2005. Considering that most of the elephant range in Angola has yet to be surveyed, the effect of the ivory trade on the population remains unknown. In October 2013 it was announced that Angola would join CITES as its 179th Party, with the Convention entering into force at the end of December 2013. This gives a glimmer of hope that the country will start reporting details of its ivory trade to CITES and ETIS and hopefully this will lead to a clampdown of the open ivory trade in and near its capital.

Magdalena S. SVENSSON, ELENA BeRSACOLA, Simon K. BEARDER and VINCENT NIJMAN Oxford Brookes University, Oxford, UK. E-mail m.svensson@brookes.ac.uk

Michael Mills A.P. Leventis Ornithological Research Institute, University of Jos, Nigeria

\section{The Endangered Andean cat and fracking in Patagonia}

In July 2013 oil giant Chevron and the Argentine YPF oil company signed an agreement opening the door to massive exploitation of shale oil and gas in one of the most biodiverse regions of the Patagonian steppe (Chehebar et al., 2013, Valoración de sitios para la conservación de la biodiversidad en la estepa y el monte de Patagonia, Administración de Parques Nacionales de ArgentinaWCS-TNC, Buenos Aires). This region is home to the most genetically distinct (Cossios et al., 2012, Endangered Species Research, 283-294) population of the most threatened cat species of the Americas, the Andean mountain cat Leopardus jacobita. The species was thought to be restricted to high Andean habitats until it was discovered in Argentina's northern Patagonian steppe at $650 \mathrm{~m}$ altitude in 2008 (Novaro et al., 2010, Cat News, 8-10). The entire currently known range of the Patagonian Andean cat lies atop the Vaca Muerta shale reserve, recently identified as one of the world's largest deposits of shale gas and oil.

During the last few decades this arid region, experiencing a trend of increasing dryness as a result of global climate change, produced 50\% of Argentina's gas and oil through conventional extraction. Shale deposits must be extracted through the unconventional method of hydraulic fracturing (fracking). At least 377 unconventional wells have already been drilled and at least 2,500 additional wells were expected by 2018. However, development stalled after the renationalization of YPF in 2012, which had been bought by the Repsol company in the 1990s. YPF owns about onethird of the oil concessions for Vaca Muerta but lacked the funds for extensive development of fracking. The controversial agreement with Chevron will initially provide USD 1.24 billion to develop 100 fracking wells and 
eventually USD 17 billion to jointly develop an additional 1,500 fracking wells (S. Romero \& C. Krauss, 2013, An odd alliance in Patagonia, New York Times, 21 October). Other international companies also have concessions within Vaca Muerta. The French company Total has requested permission for fracking within a provincial protected area (Auca Mahuida) that probably harbours the Andean cat and is home to a breeding population of the threatened Andean condor Vultur gryphus and several endemic species of lizards.

In Argentina environmental impact statements and mitigation are currently required only for individual wells. These local impact statements are inappropriate for evaluating and minimizing effects on biodiversity in general and on the rare, wide-ranging Andean cat in particular. Cumulative effects of hundreds of wells will affect not only these cats and the area's other unique wildlife but also Patagonia's largest agricultural region, renowned especially for its fruits and wines, and the more than one million people that live downstream in Patagonia's largest human population.

In the USA, after years of extensive expansion of fracking, scientists are calling for research on its cumulative effects on biodiversity (Souther et al., 2013, Letter from Society for Conservation Biology to the Environmental Protection Agency, Department of Energy, and Department of Interior. www.conbio.org/policy/scb-requests-additionalresearch-on-the-impacts-of-fracking-on-biodiversity). The Wildlife Conservation Society Argentina held a workshop in November 2012 that brought together extractive companies and government agencies for the first time to discuss the need to evaluate and address proactively the potential cumulative effects of fracking and other extractive activities on Patagonian Andean cats and other species. A strategic assessment of the effects of oil and mining projects on biodiversity, coupled with consensual planning for mitigation and compensation, could ensure that consequences are fully considered and responsibly addressed at the earliest stages of the development of this controversial method of hydrocarbon extraction. In a historical first step government and industry representatives reached a consensus at the November workshop on the need for such a process.

However, in response to protests by environmentalists, government and industry officials publicly state that there are no negative environmental effects of fracking and that the province's monitoring plan based on local effects of individual wells is sufficient for protection of the environment (R. Esquivel, Neuquén Secretary of the Environment, No hay alteraciones ambientales, Diario Río Negro, 12 October 2013). The future of the recently discovered Patagonian Andean cat may now depend on the willingness of politicians and companies to acknowledge the uncertainty about the effects of fracking, accept responsibility to consider and address cumulative effects, and set an example for other regions where shale oil and gas deposits are being discovered, by carrying out and implementing a strategic plan to minimize and mitigate effects of fracking in Vaca Muerta on biodiversity and the environment.

Susan WaLKer, Martin Funes and LARA Heidel Wildlife Conservation Society Argentina-Patagonian and Andean Steppe Program, Junin de los Andes, Neuquen, Argentina. Emailswalker@wcs.org

Rocio Palacios CONICET-Centro de Relevamiento $y$ Evaluación de Recursos Agrícolas y Naturales, Cordoba, Argentina

ANDRES NOVARO CONICET-INIBIOMA and Wildlife Conservation Society Argentina-Patagonian and Andean Steppe Program, Junín de los Andes, Neuquén, Argentina 